ISSN 2078-6441. Вісник Львівського університету. Серія географічна. 2014. Випуск 47. С. 146-151. Visnyk of the Lviv University. Series Geography. 2014. Issue 47. P. 146-151.

379.85

вітл н шуб
иївський н ціон льний університетімені
просп. лушков , 2, 03023, м. иїв, кр ён

но б льну оцінку історико-культурним ресурс м окремого дміністр тивного р йону н прикл ді гурівського р-ну иївської обл. изн чено коефіцієнт туристичної прив бливості p йону. иокремлено основні н прями можливого використ ння історичних і культурних об'єктів з ур хув нням ст ну їхньої збереженості т розт шув ння.

лючові слов : історико-культурні ресурси, б льн оцінк ресурсів, сільський туризм.

уризм сьогодні - один із видів економічної діяльності, що стрімко і дин мічно розвив ється.

європейських кр їн х т мериці ост нніми рок ми збільшується попит н сільський туризм т “відпочинок н диких територіях”. ор з більше з'являється нових екоготелів т фермерських господ рств, що вирощують екопродукцію для своїх гостей поряд з з соб ми розміщення. кту льність теми поляг є в тому, що з 2003 р. 3 офіційними д ними в кр їні зникло 171 село [7]. Дн 3 причин - безробіття н селі. олоді верстви н селення є тим потенці лом, що може вплинути н збереження укр їнського сел, тому для дослідження проведено опитув ння серед молоді одного $з$ дміністр тивних р йонів иївської обл. ет дослідження - дізн тися їхні уподоб ння, інтереси, з'ясув ти, чи б чить молодь перспективу своєї ре ліз ції через туристичний бізнес, чи є необхідні ресурси (якої кількості т якості), що в жливо в р зі пошуку можливостей з стосув ння туризму для розвитку р йону т н д ння робочих місць молодому поколінню.

ля опитув ння використ но метод нкетув ння, для оцінки історико-культурних ресурсів - б льну оцінку.

рунтовне уявлення про н строї молоді в поєдн нні з оцінкою ресурсів д дуть змогу виявити б л нс між уявленнями про можливості туризму й ре льним з безпеченням т кої можливості, дет ліз ція якої н д лі може д ти пр ктичні з ходи.

и провели опитув ння школярів ст рших кл сів т молоді гурівського р-ну иївської обл., щоб визн чити, чи б чить молодь перспективу в ре ліз ції через туристичний бізнес. ході опитув ння н селення віком від 15 до 25 років у сел х ов лекс ндрівк , т р ржиця, еревки т р сне, де н селення віком від 15 до 25 років ст новить у середньому 20-30\%, серед 480 опонентів (340 з яких - жіночої ст ті, 140 - чоловічої) $83 \%$ виявили 6 ж ння поїх ти з сел в пошук х роботи (здебільшого жінки). ише $15 \%$ згодні пр цюв ти в сільськогоспод рському секторі, $3 \%$ не б ж ють пр цюв ти вз г лі. н лізуючи т кі результ ти, можн зробити висновок, що молодь не б чить перспективи для себе н селі. туризм може ст ти дод тковою ст ттею доходів економіки гурівського р-ну т н д ти молодому н селенню робочі місця.

(C) шуб ., 2014 
зн чимо, що серед опитув них лише $32 \%$ вв ж ють сільський туризм перспективною г луззю для розвитку сел т виявляють 6 ж ння пр цюв ти в туристичній сфері. е свідчить про те, що молодь не цік виться рідним кр єм т не розуміє зн чення туризму в світовій економіці. ому ми досліджуємо ресурси, щоб д лі обгрунтовув ти перспективи розвитку сільського туризму. ісля цього можемо проводити певні з ходи зі школяр ми, вести просвітницьку діяльність через туристичні м ршрути тощо для поліпшення ст влення молоді до своєї м лої б тьківщини.

ільський спосіб життя, пізн в льний туризм, гротуризм - перспективні г лузі для розвитку укр їнського сел , відповідно, з н явності необхідних туристичних ресурсів. роблемою дослідження є оцінк історико-культурних ресурсів н невеликій територіï $[1,2]$.

б'єкт дослідження - гурівський р-н иївської обл. [6, 8]. цій місцевості нем $є$ унік льних природних ресурсів чи п м'яток культури н ціон льного зн чення, одн к, про н лізув вши н явні ресурси, ми зможемо зробити висновок про прив бливість території для розвитку сільського туризму т визн чимо перспективи для його розвитку. редметом дослідження є історико-культурні ресурси.

и н м г лися оцінити історико-культурні ресурси гурівського р-ну иївської обл.

сторико-культурні ресурси відігр ють в жливу роль у формув нні туристичного попиту т створенні прив бливого туристичного іміджу регіону чи держ ви. н шій держ ві історико-культурні об'єкти пр ктично не оцінені як туристичні ресурси, більшість визн чних п м'яток не включені в туристичні м ршрути, тому їх використовують в обмежених м сшт б х. кр їні $€$ кон “ ро охорону культурної сп дщини” [3], згідно з яким усі об’єкти культурної сп дщини поділяють н рухомі й нерухомі, 3 вид ми - н рхеологічні, історичні, монумент льного мистецтв , рхітектури і містобудув ння, с дово-п ркового мистецтв, л ндш фтні т об'єкти н уки і техніки. гідно 3 цим 3 коном, діє ерж вний реєстр нерухомих п м’яток кр їни, у якому інформ ція про кожну п м’ятку под н відповідно до к тегорії: держ вного чи місцевого зн чення.

ід історико-культурними ресурс ми розуміють окремі споруди, предмети, п м’ятні місця, пов'яз ні з історичними подіями, витвори м тері льної і духовної культури, які м ють історичну, н укову, художню бо якусь іншу культурну цінність.

думку . узик [4], історико-культурні п м’ятки, що входять і можуть увійти до скл ду туристичних ресурсів, необхідно розгляд ти не просто як окремі об'єкти з певною історичною бо культурною цінністю, як поєдн ння відповідних видів історико-культурних ресурсів, що м ють високу тр ктивність, можуть формув ти історико-культурний туристичний потенці л місцевості.

. олінов 3 пропонув л підхід, який для оцінки пізн в льної цінності містить т кі критерії: рівень орг ніз ції об'єктів для пок зу; місцезн ходження турист стосовно об'єкт огляду. рівнем орг ніз ції історико-культурні об'єкти поділяють н спеці льно підготовлені для пок зу і не підготовлені, 3 місцезн ходженням суб'єкт до об'єкт огляду - н інтер'єрні й екстер'єрні.

. цол 3 пропонув в оцінюв ти рекре ційну зн чимість території з щільністю п м’яток історії т культури н $100 \mathrm{~km}^{2}$ [5]. кий підхід можн використовув ти для оцінки історико-культурних ресурсів великих регіонів, не для визн чення історикокультурного туристичного потенці лу поселення чи н віть окремого дміністр тивного $\mathrm{p}$ йону. 
ля оцінки історико-культурних п м’яток сільської місцевості В. . ринів, . оп ч, . узик з пропонув ли б льну методику [4].

икорист н б льн методик оцінки культурно-історичної прив бливості туристичних об'єктів передб ч л оцінку компонентів п м'яток: рхеологічних об'єктів; меморі льних п м'яток, пов'яз них з історичними подіями, н ціон льно-визвольними зм Г ннями, війн ми і бойовими т культурними тр диціями; п м'ятників т п м'ятних місць, пов’яз них з життям і творчістю діячів історії, культури; п м’яток оборонного будівництв (земляні бо муров ні укріплення, з мки з б стіонними укріпленнями, мон стирі, н йновіші фортифік ційні споруди ви, костели, син гоги тощо), п м'яток н родної рхітектури (поселення, двори, господ рські й житлові будівлі, дерев'яні церкви т ін.), гром дських споруд (н родні школи, н родні доми, шпит лі, корчми, млини), п л цово-п ркових нс мблів, суч сних п м'яток рхітектури, професійних художніх промислів, н родних художніх промислів (тк цтво, килим рство, вишивк , художня обробк шкіри, художнє плетіння, деревообробк, гонч рство тощо), п м'яток м тері льної культури т п м'яток фольклору.

бчислюв ли прив бливість туристичних об’єктів, підр ховуючи б ли з т кою формулою:

$$
A=\sum_{i=1}^{1} P_{i}+\sum_{i=1}^{1} T_{i}+\sum_{i=1}^{1} S_{i}+\sum_{i=1}^{1} R_{i}+\sum_{i=1}^{1} F_{i},
$$

де - інтегр льний пок зник пізн в льної цінності окремого об'єкт території; і- компоненти п м'яток історії т культури; і- компоненти рхітектурних п м'яток; $S_{\mathrm{i}}-$ компоненти п м'яток мистецтв .

ля зручності порівняння використ но коефіцієнт туристичної прив бливості r, який д є змогу виконув ти порівняння т зіст влення різних туристичних об'єктів, к ртогр фув ння територій з рівнем їхньої туристичної тр ктивності тощо:

$$
K_{r}=\frac{R}{R_{\max }},
$$

де $R$ - сум б лів туристичної цінності ресурсів окремого об'єкт (території); $R_{\max }-$ м ксим льно можлив сум 6 лів 3 шк лою б льної системи оцінок.

підст ві зн чення г ми пропонуємо т ке р нжув ння рівнів прив бливості туристичних об'єктів (територій):

- $0,86-1,00$ - унік льні;

- $0,65-0,85$ - високо тр ктивні;

- 0,45-0,64 - середньо тр ктивні;

- $0,25-0,44-$ м ло тр ктивні;

- до $0,25-$ не тр ктивні.

ля н шого дослідження до ув ги взято 41 сільське поселення гурівського р-ну. цінку історико-культурних ресурсів виконув ли з б льною методикою. оч ця методик $є$ н р зі оптим льною для оцінки історико-культурних ресурсів невеликих $\mathrm{p}$ йонів, т все ж м є певні обмеження. дн к результ ти дослідження можн вв ж ти репрезент тивними.

гурівський р-н розт шов ний н сході иївської обл., н межі 3 ернігівською. ідст нь до н йближчого міжн родного еропорту - 85 км. $30 \mathrm{KM} \mathrm{н} \mathrm{південь}$ $€$ втомобільн тр с міжн родного зн чення иїв- рків. лощ $\mathrm{p}$ йону $-763 \mathrm{KM}^{2}$. 
гурівський р-н перев жно гропромисловий. о гропромислового комплексу входять 24 сільськогоспод рські підприємств т 105 фермерських господ рств.

ільськогоспод рські угіддя з йм ють 63,5 тис. г , з них 55,2 тис. г ріллі. сновн ч стк ріллі - під зерновими культур ми.

н ліз історико-культурних п м'яток з свідчив, що в р йоні виявлено зн чну кількість кург нів - близько 20, це приблизно $5 \%$ від з г льної кількості в иївській обл.

ж ль, їх зд вн розкопув ли шук чі ск рбів, нині нерідко розорюють н полях тр ктор ми (н прикл д, у с. т р ржиця). ких скіфських похов нь було б г то н вколо гурівки, лексіївки, ередівки (до 15 могил), рк діївки, проте сьогодні вціліли одиниці. чений в н ундуклей 150 років тому вид в опис кург нів иївської губернії. його д ними, в одному повіті иївської губернії (нині це територія двохтрьох р йонів иївської обл.) було близько 500 кург нів.

кожному селі є церкв , 3 ост нні декільк років побудов но нові церкви в тих сел х, де вони були зруйнов ні в р дянські ч си, т кож збереглося декільк д вніх дерев'яних церков. прикл д, церкв іздв вятої огородиці в с. л ерез нк побудов н в середині XVIII ст. е невелик 3 розмір ми дерев'ян споруд . основу iii пл нув ння було взято хрест. береглися к рк с будови і ч стин верхнього перекриття. еркв икол ївськ (с. ойкове) збудов н в 30-ті роки XIX ст. рхітектурн п м'ятк місцевого зн чення.

смт гурівк є п м'ятк с дово-п ркового мистецтв - дендроп рк, 3 кл дений у ст. . очубеєм. ж ль, нині п рк у з недб ному ст ні. гурівському р-ні н родилось декільк відомих історичних осіб, т ких як . ирій, відомий н ціон ліст . іхновський, письменник . едуниця, поет, музик нт, етногр ф, історик ркевич, що підтримув в дружні стосунки 3 . евченком, який приїждж в до ркевич 1847 р. у с. урівку. гурівському р-ні розвинені художні промисли, $\epsilon$ етногр фічні музеї т ін. (див. рисунок).

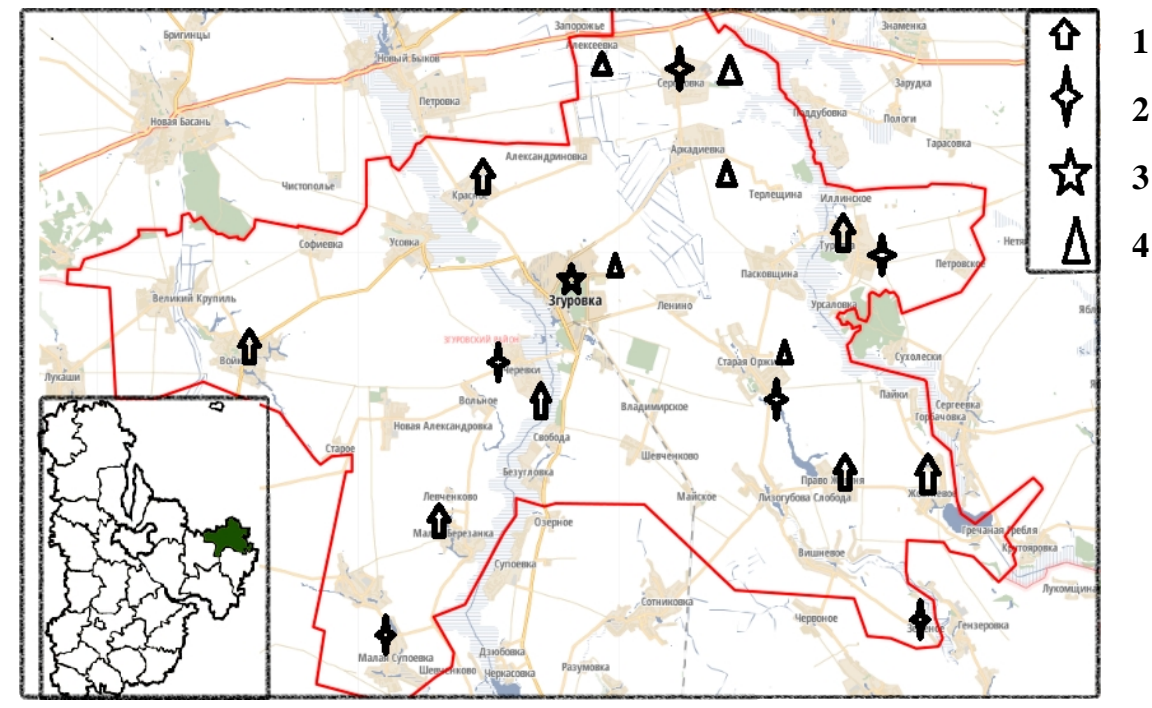

озт шув ння історико-культурних п м'яток гурівського р-ну. рт -врізк - місцезн ходження гурівського р-ну в иївській обл.: 1 - церкви; 2 - вид тні діячі; 3 - дендроп рк; 4 - кург ни 
оефіцієнт прив бливості історико-культурних п м’яток гурівського р-ну, згідно з б льною оцінкою, дорівнює 0,33, тобто входить до рівня м ло тр ктивні.

кщо в ході скл д ння м ршрутів з луч ти сусідній готинский р-н (до 25 вересня 1986 р. територія гурівського р-ну н леж л до готинського), де зн чно більш кількість історико-культурних п м'яток, що м ють високу історичну т мистецьку цінність ( обр ничівськ стоянк, місця, де був в р с евченк, музей художниці терини ілокур т ін.), відповідно, коефіцієнт туристичної прив бливості 0,45 , то це озн ч тиме, що місцевість 3 шк лою 6 льної оцінки є середньо тр ктивн .

изн чені пок зники з свідчують, що історико-культурні ресурси є в жливою, хоч й не основною скл довою туристичного потенці лу гурівського р-ну иївської обл. икорист ння ж історико-культурних ресурсів р йону недост тнє. е пов'яз но передусім з тим, що нем їхнього чіткого обліку, н лежного рівня рекл ми, нез довільним є ст н розвитку інфр структури. береженість п м'яток пог н , що зумовлене недост тнім фін нсув нням, т кож не розробленістю методик включення історикокультурної сп дщини до туристсько-рекре ційної сфери.

тже, н ші дослідження з свідчили, що молоде покоління сільського н селення не виявляє $б$ ж ння з лиш тись у селі через безробіття т з г лом з цік влене в розвитку туризму в їхній місцевості, хоч лише невелик ч стк розуміє зн чення туризму в економіці. трим ні результ ти свідч ть про необхідність под льших з ходів щодо популяриз ції туризму т просвітництв, т кож обгрунтув ння соці льноекономічних з с д ре ліз ції н явних перспектив серед молодого покоління. гурівський р-н иївської обл. м є зручне тр нспортне сполучення т історико-культурні ресурси. цінк історико-культурних ресурсів гурівського р-ну иївської обл. довел , що ця місцевість м є невеликий потенці л для розвитку пізн в льного туризму. т н історико-культурних п м'яток потребує фін нсув ння для рест вр ції, підтримки т рекл ми. ьогодні можливе використ ння в туристичних м ршрут х музеїв, відвідув ння церковних споруд т п м'яток. жливо розвив ти й міжр йонні зв'язки, розробляючи міжр йонні туристичні м ршрути н території готинського т ереясл в- мельницького р-нів. ург ни потребують збереження т внесення їх до з повідної зони. ендроп рк у з недб ному ст ні, необхідне нег йне фін нсув ння для збереження його рослинного світу.

н явності інших, н прикл д, природних ресурсів, зокрем водних, у гурівському р-ні може успішно розвив тись сільський пізн в льний туризм т сільський гротуризм. огляду н гропромислову спеці ліз цію р йону гротуризм м є більший потенці л.

ступним кроком н ших досліджень буде оцінк природних ресурсів гурівського p-ну т визн чення потенці лу для розвитку водного туризму, відпочинку в сільській місцевості. ісля повного н лізу й оцінки природно-ресурсного потенці лу, оцінки інфр структури зможемо визн чити перспективи розвитку туризму в сільській місцевості н прикл ді гурівського р-ну т розр хув ти вплив туристичної г лузі н з г льний економічний розвиток р йону.

1. ейдик. . етодологія т методик н лізу рекре ційно-туристських ресурсів кр їни : втореф. дис. н здобуття н ук. ступеня д-р геогр. н ук/ . . ейдик. ., 2004. - 36 c. 
2. ейдик . . екре ційно-туристичні ресурси кр їни : етодологія т методик н лізу, термінологія, р йонув ння / . . ейдик. - ., 2001. - . 42.

3. кон кр їни “ ро охорону культурної сп дщини”// ідомості ерховної ди. 2000. - № 39.

4. $\quad$ вців B. C. уково-методичні $з$ с ди реформув ння рекре ційної сфери : укове вид ння / В.С. р вців, . . ринів, . . оп ч, . . узик. - ьвів : кр їни, кр їни, 1999. - 78 с.

5. цол . . екре ційно-туристичний комплекс кр їни / . . цол . - ьвів, 1997. -259 c.

6. http://zgurivka-rda.gov.ua/index.html.

7. http://oblstat.kiev.ukrstat.gov.ua/content/index.php3?lang=1.

8. http://uk.wikipedia.org/wiki/ гурівський_p йон.

m ття: н дійшл до ред кцї 22.09.2014

доопр иьов н 11.10 .2014

прийнят до друку 15.10.2014

\section{EVALUATION OF THE HISTORIC-CULTURAL RESOURCES OF ZGURIVKA DISTRICT IN KYIV REGION}

\section{Svilana Kashuba}

Taras Shevchenko National University of Kyiv,

Glushkov Ave., 2, UA-03023, Kyiv, Ukraine

Analysis of historic-cultural resources of Zgurivka district as one of factors of suburban tourism forming in context of long term programs of touristic branch of Zgurivka district was made in the article. The historical and cultural resources were evaluated. Main directions of possible usage of historic and cultural objects with regard of storage quality and distribution by suburban administrative districts were defined.

Key words: historic-cultural resources, rating resources evaluation, suburban tourism. 